\title{
Globalization and Education in the 21st Century
}

\author{
Romulo F. Magsino
}

University of Manitoba

\section{ABSTRACT}

This paper provides a critical historical summary of globalization and examines various positions against and in favor of globalization. It concludes that capitalistic globalization has not achieved its central goal of global economic growth and even less of the betterment of the quality of life. The encompassing mind-set or world view that globalization fostered in peoples is problematic not only because of its cultural homogenization but because of its lack of sense of obligation to others, poor sense of the public, and private relativism. Education has a critical role to play in dealing with the problematic aspects of globalization. It is argued that a critical examination of critical pedagogy, cosmopolitism (the establishment of cosmopolitan democratic law and the establishment of a democratic community as expounded by D. Held and also relying on M. Nussbaum), and global education (mainly as proposed by P. McIntosh) should be undertaken to identify commonalities and differences and articulate a renewed pedagogical approach.

Key words: globalization, critical pedagogy, cosmopolitism, global education, cultural homogenization

\section{RESUMEN}

Este articulo provee un sumario histórico crítico de los procesos de globalización y examina posiciones en contra y a favor de la globalización. Concluye que la globalización capitalista no ha alcanzado su objetivo central de crecimiento económico y menos aun de mejoramiento de la calidad de vida. La mentalidad o visión del mundo que el proceso de globalización ha fomentado en la gente es problemática no solamente porque auspicia la homogenización cultural sino también porque carece de un sentido de obligación hacia los demás, tiene un sentido muy pobre de lo público, y fomenta un relativismo privado. La educación tiene un papel fundamental en cualquier intento para enfrentar los aspectos problemáticos de la globalización. Se argumenta aquí que es necesario que haya una examinación crítica de la pedagogía crítica, las teorías cosmopolitas ( el establecimiento de leyes democráticas cosmopolitas y de una comunidad democrática como lo expusiera D. Held y tambén sobre las bases de ideas de M. Nussbaum), y de las teorias de la educación global (siguiendo a P. McIntosh). Esta examinación permitiría identificar elementos comunes y diferencias y articular y enfoque pedagógico renovado.

Descriptores: globalización, pedagogía crítica, teorías cosmopolitas, educación global, homogenización cultural.

RÉSUMÉ

Ce papier donne un résumé historique critique de la mondialisation et examine diverses positions contre et pour la mondialisation. Il conclut que la mondialisation capitaliste n'a pas atteint son but central de croissance économique globale et encore moins d'amélioration de la qualité de vie. L'attitude d'esprit prédominante ou la cosmologie selon laquelle la globalisation encouragée chez les peuples est problématique non seulement à cause de son homogénéisation culturelle mais de 
ses manques de sens d'obligation envers les autres, de son pauvre sens du public, et de son relativisme privé. L'éducation a un rôle critique à jouer en ce qui concerne les aspects problématiques de la globalisation. L'auteur soutient qu'un examen critique de la pédagogie critique, le cosmopolitisme (l'établissement de lois démocratiques cosmopolites et l'établissement d'une communauté démocratique telle qu'expliqué par D. Held et également appuyé sur M. Nussbaum), et l'éducation globale (principalement proposée par P. McIntosh) devraient être entrepris pour identifier les traits communs et les différences et articuler une approche pédagogique renouvelée.

Mots-clés: la mondialisation, la pédagogie critique, le cosmopolitisme, l'éducation globale, l'homogénéisation culturelle.

\begin{abstract}
A t the turn of the present century, Thomas Friedman, a Pulitzer Prize-winning foreign affairs columnist for the New York Times, triumphantly declared that we are now immersed in a new international system. As he put it (Friedman, 2000, p.7),
\end{abstract}

This new system had its own logic, rules, pressures and incentives and it deserved its own name: "globalization." Globalization is not just some economic fad, and it is not just a passing fad. It is an international system that replaced the Cold War system after the fall of the Berlin Wall. We need to understand it. ... We are now in the international system of globalization.

Two issues immediately arise from Friedman's declaration: globalization as an on-going process, and the nature of globalization. His first contention, that the turn of the century marks the globalization process, has been contested by historians, some of whom believe that the year 1492 is globalization's starting date (MacGillivray, 2006, p.16). Apparently some forms of globalization existed during the Arab Empire, the Mongol Empire, the 16th century, and particularly the 17th century, when the Dutch East India Company, often described as the first multinational corporation, was established (Wikipedia, 2007, p.2). The 19th century, frequently regarded as the first era of globalization, saw the rapid growth of international trade and investment between the European imperial powers, their colonies and, later, the United States (Wikipedia, ibid.). In the last few decades, advances in technology and the spread of capital have obviously intensified the globalization process. Thus, not surprisingly, MacGillivray (2006, p.17) concludes that "globalization develops in a jerky, not gradual fashion," and that "There have been just a handful of short pulses of hyper-globalization." In his view, we can pinpoint five globalizing decades over the last five centuries, which were characterized by a "concatenation of commercial, social, financial, cultural, and technological events that markedly and rapidly shrank the globe" (ibid, p.18). Contraction 1, the Iberian Carve-Up, occurred between 1490 until 1500, during the global competition between Spain and Portugal, which carved-up the globe into their respective areas of exploration, control, and exploitation. Contraction 2, the Britannic Meridian, from 1880 to 1900 , during the British Empire's domination of the world, was marked not only by modern corporations' expanding their global reach, but also by round-the-world trips and luxurious enjoyment of exotic goods on the part of the wealthy. Contraction 3, the Sputnik World from 1955 to 1965, was the golden age for economic growth and trade in many parts of the world, during which corporations 
began to flex their multinational muscles and technological and cultural innovations were widely adopted and enjoyed. Contraction 4, the Global Supply-Chain, from 1995 to 2005, saw not only the establishment of supply chains of giant multinationals in various countries of the world, from West to East and from North to South, but also extensive interaction through air travel and fibre-optic web and mobile telephone masts, "allowing one billion people to communicate, collaborate, and compete as never before." Contraction 5, for which MacGillivray is unable to provide definite dates, could come in 20 or more years; it may be expected to "present huge economic, social, cultural, and environmental challenges..., which could make all previous experiences of globalization look like false labour" (2006, pp. 19-21).

As MacGillivray's analysis shows, globalization is an on-going, saltatory process, which started centuries ago and whose end result is presently unknown. Thus, Friedman is not exactly right in giving the impression that globalization started with the fall of the Berlin Wall and that we have arrived at the state where all the features of globalization have been attained and are fully at work. Nonetheless, his later analysis (pp.17-25; also, Held, 2006, pp.290-304; MacEwan, 1999, pp.27-29) proves revealing with respect to the nature or defining features of present-day globalization. As he points out, globalization at the turn of the twenty-first century has a number of recognizable characteristics, including the following (Friedman, 2000, p.9). First, it has one over-arching feature, namely, integration. The world has become an interwoven place where extensive interconnection happens, particularly through the web. This interconnection facilitates the dynamic, "inexorable integration of markets, nation-states, and technologies to a degree never witnessed before - in a way that is enabling individuals, corporations and nationstates to reach around the world farther, faster, deeper, and cheaper than before, and in a way that is enabling the world to reach into individuals, corporations, and nation-states farther, faster, deeper, and cheaper than ever before." Second, globalization's driving idea is market capitalism, which propelled the spread of free-market capitalism all over the world through capitalism's set of rules, including opening, deregulating, and privatizing every country's economy for greater competition and foreign investment. Third, globalization has a tendency to homogenize culture; under present global conditions this tendency is toward the Americanization of the cultures of other countries. Fourth, globalization's integrative capacity results from its defining technologies, particularly computerization, miniaturization, digitization, satellite communications, fiber optics, and the internet. Fifth, globalization's defining measurement is speed - speed of commerce, travel, communication, and innovation; globalization enables individual countries to progress at a rapid pace; slow-moving countries will be left behind. Sixth, globalization's defining economists are Joseph Schumpeter, who advocated the destruction of old and inefficient products or services and their replacement by creative and efficient ones, and Intel chairman Indy Grove, who popularized the need for dramatic, industry-transforming innovations. Seventh, and most importantly, globalization has its own defining structure of power, which is built around three balances: balance between nation-states, balance between nation-states and global markets, and balance between nation-states and individuals who are able to muster resources and mechanisms to influence both the market and nation-states. 
Whatever configuration globalization might assume in the future (as anticipated in MacGillivray's Contraction 5), and however encompassing it is now and will be in the future, it is indeed upon us. Notwithstanding the lack of global participation in many countries in Asia, Africa, South and Central America, and Eastern Europe (Ajayi, 2001; Gondwe, 2001; Sosa, no date), globalization is very much a reality to which individuals and groups in developed countries have to react in one way or another. Certainly the reaction has been passionate in conflicting ways between globalists and anti-globalists. Disturbed about the impact of globalization, authors (including Herman Daly, David Korten, and Walden Bello) in The Case Against the Global Economy (Mander \& Goldsmith, 1996), Edward Luttwak (1999), Gary Teeple (2000), and Leslie Sklair (2002), among many others, have highlighted the case against globalization, while Martin Wolf (2004), Jagdish Bhagwati (2004), George Soros (2000), and the Centre for Trade Policy Studies of the CATO Institute (2007), among many others, have spiritedly tried to explain and defend globalization and free trade.

Undoubtedly the crucial issue for anti-globalists centres on the role of capitalism as the driving force in globalization. Thus, Sklair contends that this ideology, which Friedman and other neo-liberals like him see as the salvation of mankind mired in economic problems, has brought about "the rise of massive globalizing corporations, the rapid spread of so-called free trade, the oft-cited weakening of states and governments, the penetration of mass media (promoting what I have termed the culture-ideology of consumerism) to all corners of the globe, and the denationalization and privatization of former state monopolies" (2002, p.4. Also, Teeple 2000, pp.81-131). For neo-liberalism, however, these developments are a matter of necessity: they are needed to ensure increased trade, integration of global economy, and economic growth throughout the world. Globalization is unequivocally important and benevolent, and huge transnational corporations are the efficient instruments for spreading its benefits to peoples around the globe. As efficient instruments, they also expand consumers' options and reduce the prices of goods and services; in turn, reduced prices provide the consumers with greater purchasing power. More importantly, because "Quite simply, rapid, market-led growth is the most potent weapon against poverty that mankind has ever known" (Summers, in Peters, 2004, p.57. Also, Dawer, no date; Sosa, no date) and because globalization engenders that growth, countries particularly in the third world need to globalize.

That capitalistic globalization promotes development around the globe is an article of faith among neo-liberals. This appears evident among industrialized countries, and this is no truer than in the United States, whose giant transnational corporations have dominated the globalization process through the sheer power of their enormous wealth and influence and through the establishment of trading rules favourable to them (Derber, 2002). However, that capitalistic globalization has actually alleviated the conditions of the peoples in Third World countries remains quite debatable. While the central moral argument for the rapid global expansion of the unregulated market place is the claim that living standards will rise faster and that incomes will converge, the reality is something else. The deregulation of the world's products and financial markets has enriched a world class of investors, entrepreneurs, and professionals, while prosperity 
has barely touched the poor everywhere (Faux \& Mishel, 2000, pp. 93-94). In their study for the World Bank, Chen and Ravallion (2004) provide a mixed picture: “...(I)t is no cause for complacency. The 390 million fewer poor by the $\$ 1$ per day standard over the 1981-2001 are still poor by the standards of middle-income developing countries, and certainly by the standards of what poverty means in rich countries. And our estimates indicate that the number of people under $\$ 2$ per day has actually risen. Clearly a great many people remain poor and vulnerable to aggregate economic slow down" (2004, p.24). Further, globalization has not ensured a stable and strong economy for developing countries either: as Faux and Mishel point out, "Mexico, Thailand, Indonesia, Korea, Brazil, and at times even Russia, adorned the gallery of nations whose economies soured shortly after their leaders were lauded by the global policy elite for pursuing sound economic fundamentals.... Even more troubling has been the apparent growth of inequality within nations - especially the most developed" (ibid., p.94). Also, though significant narrowing of the gap between some developing and developed countries has been attained, many more developing countries have seen the economic gap actually widen (Soubbotina, 2000, p.90. Also, MacGillivray, 2006, pp.285-289).

Clearly, capitalistic globalization has not achieved its central goal of global economic growth, not to speak of the betterment of the quality of life in its different dimensions in many countries. However, notwithstanding its "one-dimensionalism, its one-way-street linear thinking, (and) its world-market authoritarianism," sympathetic writers see it working in the long term, given some important adjustments and control (Beck, 2000; p.129; also, Bhagwati, 2004; Stiglitz, 2002, 2007; Wolf, 2004). Others, including the anti-globalization demonstrators in Seattle protesting against the World Trade Organization, remain opposed to the "cowboy capitalism" of the presently dominant globalization and they advocate a form of globalization that pursues global democracy and justice for the global poor (Derber, 2002, p.206). Some socialists, on the other hand, believe that socialist globalization, which would address the issues of democracy, human rights, and socialism, is not only possible, but also necessary. Finally, others, who have religious perspectives, argue for a form of globalization that would reconnect people and the earth and welcome the struggle of people's movements for global solidarity (Peters, 2004). Regardless of the form of globalization that rises prominently to challenge the current capitalistic form of globalization, a sober reminder from Lester Thurow (1996) about today's reality that a global economy exists, cannot be discarded:

Stopping its development might not have been hard at the beginning, but dismantling it now would be very difficult - most likely impossible. A global economy now shapes everyone's view of the world and alters how each of us thinks. Everyone faces a new reality. Everyone is mutually interdependent and linked in very different patterns of supply and demand than might otherwise have existed... In a very real sense the global economy has become physically embodied in our ports, airports, and telecommunications systems. But most important, it is embodied in our mind-sets. 
Were globalization problematic simply because it has not delivered, so far, on its promise of global economic growth and, thus, improvement in the conditions of the developing countries in the world, it would not be inappropriate to give it the benefit of the doubt and to hope that in due course of time, its current capitalistic processes will eventually bring about its promised benefits. Unfortunately, the encompassing mindset or world view that it has fostered in peoples it has touched is not only culturally homogenizing, but is also problematic.

The world view that capitalistic globalization has brought to different countries has pervasively influenced not only the workings of trade and industry within and among nations, but has also shaped the global culture. Observed presciently by Marshall McLuhan and Powers (1989) about two decades ago, the technologically sophisticated mass media, particularly television and the internet, have facilitated the instantaneous exposure of people to same ideas and beliefs, values and life-styles, and institutional practices through graphic images and sounds. Through global cultural flows - of people, images, machinery, money, and ideas - now what McLuhan and Powers called the global village has become saturated with the culture industries. Film, radio, television, recording industry, shopping malls, destination entertainment centres, themed cities, theme parks, fashion, cuisine, gambling, professional sports, and games, are the fastest growing sector of the global economy, as Rifkin observes (2000, p.140).

Whether local cultures will survive in the face of an advancing global culture may not be disturbing if it can be shown that the latter brings with it a superior culture or way of life worthy of adoption by local communities. Unfortunately, free from nationstates' regulations and free to maximize their activities in never-ending, vigorous pursuit of profit, corporations employ the media to effectively and efficiently shape the consumers' taste (Barber, 2007). The result is a consumer culture that manipulates children to consume from an ever younger age and convinces adults to remain as infantile as possible, like their young. In Barber's (p.20) cryptic and disturbing words,

To the disorderly rulers of ancient Athens, the philosopher Socrates once said (that) for justice to prevail, you must make kings philosophers or philosophers kings. Today's sophists of marketing offer an analogous if less noble formula: for consumer capitalism to prevail you must make kids consumers or consumers kids.

Even more disturbingly he reminds us (p.108):

...(T)he infantilist ethos is fortified by an ideology of entitlement in which human beings are seen first of all as individuals - what political scientists might call rights-bearing legal persons - rather than as family members, lovers, kin-people, or citizens of a civic community. This ideology is closely associated with American individualism and the modern ethos generally, and it spurns the ethics of obligation and responsibility that place the individual in a circle of sociability in which identity is given in part by association with and duty towards others. 
Lacking a sense of obligation to others, and thus a sense of any public to which one is accountable, individuals become mired in their relativistic private and unexamined desires and preferences and, following human nature's tendency toward gratification or pleasure, forsake the demands of reflective reason. Needless to say, this has a regressive impact on society: “...major civilizations and religions... share a common conviction that the time must come when adults put away childish things, civilize their instincts, and grow up" (Barber, 2006, p.111). If they do not, the decay of human civilization becomes inevitable.

Mindful of the debilitating impact of capitalistic globalization on culture, writers have sought to explain the hegemony of transnational corporations in the international landscape, notwithstanding the globalists' insistence that globalization is founded on three balances: between nation-states, between nation-states and global markets, and between nation-states and individuals (Friedman, 2000, p.9). Unfortunately, professed balance can easily be trumped by vested interests and this is what has happened, if the analysis of globalization's failures by the 2001 Economics Nobel Prize Winner, Joseph Stiglitz (2002) is correct. Though convinced that "globalization - the removal of barriers to free trade and the closer integration of national economies - can be a force for good and that it has the potential to enrich everyone in the world, particularly the poor" (p.ix), he despairs of its failure. What went wrong, as he sees it, could be explained by examining the operation of the three main institutions that govern globalization, namely, the International Monetary Fund (IMF), the World Bank (WB), and the World Trade Organization (WTO), together with a number of the United Nation's agencies.

The IMF, responsible for ensuring global economic stability is, in particular, the target of Stiglitz's scathing criticism. He charges that the International Monetary Fund (IMF) made mistakes in all the areas in which it has been involved and that its remedies failed more often than worked, led to hunger and riots in many countries, and resulted in even greater poverty. This would not be a surprise because "countries were expected to follow the IMF guidelines without debate" and that IMF decisions were made based on a "curious blend of ideology and bad economics, dogma that sometimes seemed to be thinly veiled special interests" (2002, pp. xiii-xiv). This would not be surprising. Originally founded to remedy the unfortunate operation of the market, "it now champions market supremacy with ideological fervor." Today, it provides funds typically only if countries engage in policies like cutting deficits, raising taxes or interest rates that lead to a contraction of the economy, or rapid trade liberalization. Indeed, for Stiglitz, IMF all too often pursued policies laid down by the "Washington Consensus" (p.3-22). An insider in the workings of primary global institutions involved in international economic development, Stiglitz confirms what critics of capitalist globalization have alleged against it: given its neo-liberal orientation, capitalist globalization inescapably has to put profit before people. It appears, therefore, that it is imperative that it should be curtailed or reformed, or that alternatives will have to be found and pursued by well-meaning global institutions.

In Stiglitz's view, it is fortunately possible to reform capitalist globalization: "The most fundamental change that is required to make globalization work in the way that it 
should is a change in governance" (2002, p.226). One of the first steps is to reform the IMF and the global financial system, the World Bank and its development assistance, and the World Trade Organization (pp.229-246), together with the adoption of some measures that will introduce a new financial architecture in the international system (Soros, 2000, pp.270-300). Further, new strategies to promote transparency and accountability of transnational corporations will have to be initiated: the involvement and empowerment of employees and workers through shared ownership, proposed by Jeff Gates (1998, 2000), may have to be considered.

Promising as these proposal might be, it is doubtful that by themselves they will succeed in their effort to reform capitalist globalization, together with their institutional apparatus and their associated enticing way of life. The deeply entrenched mind-set, which Thurow has brought to our attention, can be dislodged only through the concerted effort not only of financial institutions and their movers, but also of the public at large, including the young people that transnational corporations have captivated through the use of the media. If this is the case, undoubtedly education has an important role to play in dismantling the capitalist cobwebs in the public mind. Young and old alike will have to understand the workings of the global society. However, as Robert Reich (in Beck, 2000, p.137) puts it, "Policy makers have failed to understand that a nation's real technological assets are the capacities of its citizens to solve complex problems of the future." Needed is the kind of education that will make it easier for everyone to understand and deal with the difficulties of transnational communication and conflict. And it should provide them with a cognitive map of the many dimensions and traps of 'glocal' living and action" (Beck, ibid., p.138).

The "communication and conflict", as well as the "many dimensions and traps" of living and action are, needless to say, extensive and pervasive. Indeed, concern about the wide-ranging deleterious impact of capitalist globalization has forged coalitions of civic minded individuals, groups, organizations and agencies, which have mounted resistance against dominant capitalist forces. Despite its lack of central organization and a diffused focus, nonetheless grassroots resistance is seen in the extensive networking of individuals, groups, and organizations through the internet and it gathers a strong demonstrative energy at important points, which indicate an underlying phenomenon of dissatisfaction and desire for change on the part of people in different parts of the world. Peters believes that successful protests at the various sites of the World Trade Organization's conferences show the depth of disillusionment with capitalist globalization on the part of at least two resisting coalitions: (1) those who are convinced that capitalist globalization has to be resisted because it is a new form of colonialism that fosters marginalization, dependency, and subservience on the part of politically weak and economically impoverished countries; and (2) those who are convinced that the capitalist goal of economic progress is unsustainable and will eventually bring about environmental degradation and spoliation (Peters, 2004, pp.101-170). Such coalitions are, needless to say, important forces to focus on the ills of globalization. But their occasional, though dramatic, appearances on the global scene, educational as they might be because they serve to inform people about issues that should concern them, cannot wield the sustaining power to counteract globalization's capitalist mind- 
set. As Barber (2007) points out, the media have succeeded in infantilizing both young and adults and have rendered them incapable of exercising critical, reasoned judgements in the face of consumerist enticements.

The global village clearly needs vigorous efforts on the part of school systems and concerned educators in order to remedy, at least in some significant ways, the ills brought by capitalist globalization. Such efforts have to be a concerted one, and would need the coalition of variedly focused educational theorists and advocates, such as critical pedagogy educators, cosmopolitan educators, and global educators.

Critical pedagogy theorists suggest that schools should take seriously "the imperative of educating students to affirm moral principles that renounce social injustices and encourage students to become involved in the world in order to change it" (Giroux, 1988a, p.14). Needed, further, is the adoption of a "public philosophy that gives credence to an emancipatory form of citizenship that puts equality and human life as its center and equates democracy not with privileges but with democratic rights that ensure meaningful participation in the political, economic, and social spheres of society" (ibid.). It encourages educators to make the "pedagogical more political, and the political more pedagogical." Doing so involves transforming schooling as part of a fundamental social project to help students to overcome economic, political, and social injustices. Emancipating students for this purpose necessitates the use of forms of pedagogy that treat students as critical agents, present received knowledge as problematic, use critical and affirming dialogue, and argue the case for a better world (Magsino, in Hebert, 2002, p.67). A leading critical pedagogy theorist, Giroux insists that teachers, who are "transformative intellectual," should "take seriously the need to give students an active voice in their learning experiences. It also means developing a critical vernacular that is attentive to problems produced at the level of everyday life, particularly as they are related to pedagogical experiences connected to classroom practice" (Giroux, 1988b, p.127).

Critical pedagogy theorists (for example, Apple, 1882; Freire, 1978; Giroux, 1988b, 1988b, 2004; and McLaren, 1989) have significantly brought an important thrust to schooling during the past few decades. Unfortunately, for one reason or another, they do not seem to have developed a cadre of teachers numerous enough to generate any substantial impact in school systems and in society. Perhaps few are prepared to accept their radical-sounding rhetoric; perhaps their abstract theorizing has not found translation of their views into concrete practice; or perhaps their language, adorned with overwhelming jargon and abstractions, is simply beyond the ken of other theorists, not to speak of classroom practitioners. Whatever the reason is, it is important that they should forge alliances with other educational reformers to attain their objectives. Thus, it appears encouraging that currently another response to globalization - cosmopolitanism - is making itself felt in academic discourse and in educational thought.

David Held has offered three broad, complimentary accounts of cosmopolitanism. The first conception is associated with the Stoics of the antiquity, who, explicitly professing themselves to be cosmopolitans, sought "to replace the central role of the polis ...with that of the cosmos, in which humankind could live in harmony" (Held, in Kuper, 2005, p. 190). Each person is a citizen of the world and owes prior allegiance to 
the worldwide community of human beings. As such, the individual and his/her actions are to be judged according to universal standards rather those of a single political community. The second conception draws from Immanuel Kant, who saw humans' distinctiveness in their ability to "step out of their entrenched positions in civil society and enter a sphere of reason free of dictatorial authority," ... "examine the one-sidedness, partiality, and limits of everyday knowledge, understanding, and regulations," and "come to an understanding with others about the nature and appropriateness of the demands made upon them" (ibid.). The third, more recent conception, involves three key assumptions: (1) the ultimate units of moral concern are individual human beings, not states or other particular forms of human association; (2) every living person has equal worth and has an equal stake in the universal ethical realm; and (3) each person should enjoy the impartial treatment of their claims, which not only requires a moral frame for specifying rules and principles that can be universally shared, but also rejects as unjust all those practices, rules, and institution anchored in principles that not all can adopt (ibid., pp.190-194).

If contemporary globalization is to promote democracy, it requires, in Held's view, the "implementation of cosmopolitan democratic law and the establishment of a community of all democratic communities - a cosmopolitan community..." (Held, in Shapiro \& Hacker-Cordon, p.106). In such a cosmopolitan community, the nation state "withers away," that is, it becomes no longer the sole center of legitimate power within its borders. "Cosmopolitan law would demand the subordination of regional, national, and local sovereignties to an overarching legal framework," where "associations would be self-governing at different levels". Under this system of governance, "people would come to enjoy multiple citizenships .... They would be citizens of their immediate political communities, and of the wider regional and global networks which impacted upon their lives" (p.107. Also, Held, 2006, pp.304-311)

Held's views have been met with criticism (e.g., Kymlicka, 2001, pp.317-326). However, he has received strong echo from Martha Nussbaum, who draws her inspiration from the ancient Stoics. Following Diogenes, she accepts that "The accident of where one is born is just that, an accident; any human being might have been born in any nation.” Thus, “...we should not allow differences of nationality or class or ethnic membership or even gender to erect barriers between us and our fellow human beings. We should recognize humanity wherever it occurs, and give its fundamental ingredients, reason and moral capacity, our first allegiance and respect" (Nussbaum, 2002, p.7. Also, Nussbaum, 1997, 59-67). This implies that every individual must enjoy equal rights and freedom, wherever they are.

Nussbaum has been criticized extensively by those who find her denigration of national citizenship unjustified (e.g., Jusdanis, 2001, pp.203-205), those who insist that her commitment to universalism minimizes the importance of close interpersonal relations under localized circumstances, (Lukes, 2003, pp.20-24) and those who have responded to her thought-provoking essay on "Patriotism and Cosmopolitanism" (Nussbaum, 2002). Nonetheless, it can be argued that Nussbaum and Held for that matter, are headed in the right direction. Unquestionably, there is a need for greater understanding, respect, and cooperation across national and other boundaries (Bok, 
2002, p.38), as well as acceptance of the principle that human rights and allegiance to human community should have a central place in our ethical convictions (Falk, 2002, p. 53). A close reading of their proposals would also show their recognition of the local allegiances and circumstances in a widening, concentric spiraling of human relationships and obligations. Indeed it only fair to say that they are in agreement with Roland Robertson (Beck, 2000, pp.47-52), who insists that the local and the global are not mutually exclusive, and who has suggested that the concept of cultural globalization be replaced with the concept of glocalization. Thus it is important to note what Nussbaum (1997) proposes for a cosmopolitan education to see the connection between the local and the global; as she puts it:

This education must be multicultural education, by which I mean one that acquaints students with some fundamentals about the histories and cultures of different peoples. These should the major religious and cultural groups of each part of the world, and also ethnic and racial, social and sexual minorities within their own nation; world citizens will legitimately devote more attention and time to their own region and history, since it is above all in that sphere that they must operate; ... (I)t is extremely important that this material be presented in a way that reminds the student of the broader world of which the Western traditions are a part; Education for world citizenship need to begin early. As soon as children engage in storytelling, they can tell stories about other lands and other peoples; This exposure to foreign and minority cultures... is an education for all students, so that as judges, as legislators, as citizens in whatever role, they will learn to deal with one another with respect and understanding. And this understanding and respect entail recognizing not only difference but also, at the same time, commonality; not only a unique history, but also common rights and aspirations and problems (pp.68-69).

Whether inspired by Nussbaum and/or Held, or not, Audrey Osler and Hugh Starkey (2005) are certainly headed in the same direction as their more theoretically oriented counterparts. Mindful that "education has a critical role to play" in enabling individuals to respond to globalization and that they need "to understand the links between their lives and those of others, both locally and globally" (2005, p.1), Osler and Starkey not only demonstrate the importance of cosmopolitan citizenship and what such citizenship is like, but also charts the curriculum and the processes that cosmopolitan citizenship requires.

The coalition for the reform of capitalist globalization through education could profit from still another camp of writers whose works are in the area of global education and who focus on global citizenship. An expert in the area of multicultural education, James Banks (2001) recognizes that, in a global society, "it is important for students to develop global identifications and the knowledge, attitudes, and skills needed to become effective and influential citizens in the world community" (pp.56-57). Global education is needed, as he (p.58) sees it, to enable students to develop a sophisticated understanding of their roles in the world community; 
- to understand how life in their communities influences other nations and the international events that they hear about in their daily lives;

- to understand the interdependence among nations in the modern world; and

- to develop a clarified attitude towards other nations and a reflective identification with the world community.

A key objective of global education is the development of the global citizens. Peggy McIntosh (in Noddings, 2005), sees global citizenship in terms of capacities, namely, of the mind, of the heart, and of the body and soul. The capacities of the mind include (1) the ability to observe oneself and the world around him/her; (2) the ability to make comparisons and contrasts; (3) the ability to "see" plurally as a result; (4) the ability to understand that both "reality" and language come in versions; (5) the ability to see power relations and understand them systemically; and (6) the ability to balance awareness of one's own realities with the realities of entities outside of one's perceived self. The capacities of the heart include (1) the ability to respect one's own feelings and delve deeply into them; (2) the ability to become aware of others' feelings and to believe in the validity of those feelings; (3) the ability to experience in oneself a mixture of conflicting feelings without losing a sense of integrity; (4) the ability to experience affective worlds plurally while keeping a gyroscopic sense of one's core orientations; (5) the capacity to wish competing parties well; (6) the ability to observe and understand how the "politics of location" affect one's own and others' positions and power in the world; and (7) the ability to balance being heartfelt with a felt knowledge of how culture is embedded in the hearts of ourselves and others (McIntosh, in Noddings, p.23). The abilities of the physical body, on one hand, involves the "Knowledge of self and the other, comparison and contrast between the self and others, plural understanding of the integrity of other beings, and a sense of balance between dependence and interdependence in the physical world" (ibid., p.24). On the other hand, the abilities of the soul include the "Knowledge of our mortality and the knowledge that being born entails dying...” (ibid.). For the global educators, schooling could facilitate global education through the development of sound gender perspectives (McIntosh, in Noddings, pp. 22-39), the teaching of conflict resolution strategies (Smith \& Fairman, in Noddings, pp. 40-56), the teaching of the role of one's locality and environment in relation to the global village (Noddings, in Noddings, pp.57-68); the incorporation of internationalism into the social studies curriculum (Thornton, in Noddings, pp. 81-92), and the teaching about religious pluralism in public schools (Nash, in Noddings, pp. 92-106).

Undoubtedly a detailed, complicated analyses of the nature, goals, and instructional processes, content, and context proposed by critical pedagogy, cosmopolitan education, and global education will have to be undertaken if we are to identify their commonalities and differences. Whether doing so will be a productive endeavour is difficult to tell. The coalition of variously oriented protesters against the World Trade Organization in Seattle and elsewhere were successful enough in torpedoing some of the plans of this capitalist institution; a coalition of the three types of educators may have success, 
as well, in promoting their goals, if only they would coordinate their efforts. However, unless they do so in a vigorous and sustained manner, capitalist globalization will remain entrenched in the corporate and the public mindset.

\section{References}

Apple, M. (1982). Education and power. London: Routledge and Kegan Paul.

Banks, J. (2001). Cultural diversity and education. Needham Heights, MA: Allyn \& Bacon.

Barber, B. (2007). Consumed. New York: W.W. Norton \& Company, Inc.

Beck, U. (2000). What is globalization? Malden, MA: Blackwell Publishing.

Bhagwati, J. (2004). In defense of globalization. Oxford. Oxford University Press.

Bok, S. (2002). From part to whole. In Martha Nussbaum (ed.), For love of country? Boston, MA: Beacon Press.

CATO Institute. (2007). “CATO research areas." http://www.cato.org/research/tradest.htdml

Chen, S. \& Ravallion, M. (2004). "How have the world's poorest fared since the early 1980s? New York: World Bank.

Dawer, M. (no date). A demonstration of globalization's benefits for the economies of the world. Plano, TX: manuscript.

Derber, C. (2002). People before profit. New York: Picador.

Falk, R. (2002). Revisioning cosmopolitanism. In Martha Nussbaum (ed.), For love of country? Boston, MA: Beacon Press.

Faux, J. \& Mishel, L. (2000). "Inequality and the global economy.” In Will Hutton \& Anthony Giddens, eds., Global capitalism. New York: The New Press.

Freire, P. (1978). Education for critical consciousness. New York: Seabury Press.

Friedman, T. (2000). The lexus and the olive tree. New York: Anchor Books.

Gates, J. (1998). The ownership solution. New York: Perseus Books.

Gates, J. (2000). Democracy at risk. New York: Perseus Books.

Giroux, H. (1988a). Schooling and the struggle for public life. Minneapolis, MN: University of Minnesota Press.

Giroux, H. (1988b). Teachers as intellecturals. New York: Bergin \& Garvey.

Giroux, H. (2004). The terror of neo-liberalism. Boulder, CO: Paradigm Publishers.

Held, D. (1999). The transformation of political community: rethinking democracy in the contextof globalization. In Ian Shapiro, I. \& Casiano Hacker-Cordon (eds.), Democracy's edge. New York: Cambridge University Press.

Held, D. (2005). Globalization, corporate practice, and cosmopolitan social standards. In Andrew Kuper (ed.). Global responsibilities. New York: Routledge.

Held, D. (2006). Models of democracy. Stanford, CA: Stanford University Press.

Jusdanis, G. (2001). The necessary nation. Princeton, NJ: Princeton University Press.

Kymlicka, W. (2001). Politics in the vernacular. Oxford: Oxford University Press.

Lukes, S. (2003). Liberals and cannibals: The implications of diversity. London: Verzo.

Luttwak, E. (1999). Turbo capitalism. New York: HarperCollins.

MacEwan, A. (1999). Neo-liberalism or democracy? London: Pluto Press.

MacGillivray, A. (2006). Globalization. London: Robinson.

Magsino, R. (2002). From eclectic theory to coherence: Citizenship virtues for our time. Toronto: University of Toronto Press.

Mander, J. \& Goldsmith, E. (1996). The case against global economy. San Francisco: CA, The Sierra Club.

McIntosh, P. (2005). Gender perspectives on educating for global citizenship. In Nel Noddings (ed.), Educating for global awareness. New York: Teachers College Press. 
McLaren, P. (1989). Life in schools. Toronto: Irwin.

McLuhan, M. \& Powers, B. (1989). The global village: Transformations in world life and media in the 21st century. New York: Oxford University Press.

Nash, R.J. (2005). A letter to secondary teachers: Teaching about religious pluralism in The public schools. In Nel Noddings (ed.), Educating for global awareness. New York:Teachers College Press.

Noddings, N. (2005). Place-based education to preserve the earth and its people. In Nel Noddings (ed.), Educating for global awareness. New York: Teachers College Press.

Nussbaum, M. (1997). Cultivating humanity: A classical defense of reform in liberal education. Cambridge, MA: Harvard University Press.

Nussbaum, M. (2002). Patriotism and cosmopolitanism. Boston, MA: Beacon Press.

Osler, A. \& Starkey, H. (2005). Changing citizenship. New York: Open University Press.

Rifkin, J. (2000). The age of access. New York: Jeremy P. Tarcher/Putnam.

Peters, R. T. (2004). In search of the good life. New York: Continuum.

Sklair, L. (2002). Globalization . Capitalism and its alternatives. Oxford: Oxford University Press.

Smith, S. N. \& Fairman, D. (2005). The integration of conflict resolution into the high school curriculum: The example of workable peace. In Nel Noddings (ed.), Educating citizens for global awareness. New York: Teachers College Press.

Sosa, K. (no date). Globalization and economic development in the third world: Hazard Or enhancement? Manuscript.

Soros, G. (2000). Open society: Reforming global capitalism. New York: Public Affairs.

Soubbotina, T. (2000). Beyond economic growth. Washington, D.C.: The World Bank.

Stengel, B. (2002). Cause for Worry or Agenda for Action? Educational Theory, 52(3).

Stiglitz, J. (2002). Globalization and its discontents. New York: W.W. Norton.

Teeple, G. (2000). Globalization and the decline of social reform. Aurora, ON: Garamond Press. Thornton, S.J. (2005). Incorporating internationalism into the social studies curriculum. In Nel Noddings (ed.), Education for global awareness. New York: Teachers College Press.

Thurow, L. (1996). The future of capitalism. New York: William Morrow and Company, Inc.

Wikipedia. (2007). Globalization. http://en.wikipedia.org/wiki/Globalization.

Wolf, M. (2004). Why globalization works. New Haven, CT: Yale University Press. 